\title{
Malé zamyšlení nad Národní účetní radou
}

Vážení čtenáři,

již v několika minulých číslech jste byli informováni o založení a aktivitách Národní účetní rady. Ráda bych se dnes zamyslela nad rolí tohoto subjektu v českých podmínkách. Žádná jiná evropská země nemá žádný takové sdružení, které by spojovalo Komoru auditorů ČR, Komoru daňových poradců ČR, Svaz účetních a Vysokou školu ekonomickou, fakultu financí a účetnictví. Jsme tedy jediní v Evropě, kterým se podařilo do společného sdružení přivést všechny profese zabývající se účetnictvím a sjednotit je ke společnému cíli.

Národní účetní rada se původně věnovala připomínkování účetních předpisů, zejména zákona o účetnictví, zákona o auditorech, obchodního zákoníku a daňových předpisů, tak by byla vhodným a kvalifikovaným oponentem českému zákonodárci, tj. Ministerstvu financí či Ministerstvu spravedlnosti. V dalších letech se soustředila na prezentování odborných názorů na podněty, které přicházely z praxe. Za tímto účelem vytvořila systém tvorby Interpretací českých účetních předpisů, které mají za cíl vysvětlit a nabídnout řešení pro situace, které bud' nejsou řešeny vůbec $\mathrm{v}$ českých účetních předpisech, nebo jsou v praxi řešeny nesprávně či nejednotně.

Vztah Národní účetní rady a Ministerstva financí, odboru účetnictví, nebyl od samého počátku příliš harmonický. Postupem času však systém Interpretací našel u zákonodárce pozitivní ohlas, což se projevilo implementací řešení navržených Národní účetní radou do účetních předpisů. Jednalo se zejména o názory formulované v Interpretaci $I-11$ Srovnatelnost informací za běžné a minulé účetní období v individuální účetní závěrce podnikatelì a v interpretaci I-14 Okamžik vykázání nároku na přijetí nebo vrácení dotace.

Bohužel české Ministerstvo financí už řadu let věnuje své síly reformě účetnictví státu a na regulaci a přizpůsobování účetnictví pro podnikatele novým ekonomickým podmínkám nezbývá pracovníkům př́liš mnoho času a sil. Lze tak prohlásit, že aktivity a názory Národní účetní rady si získávají v odborné veřejnosti stále více příznivců. Jedním z důvodů pro to jsou i vzdělávací akce. Od roku 2008 uspořádala Národní účetní rada několik seminářu v Praze, jejichž cílem bylo představit Interpretace a novinky v účetních a jiných předpisech, na jejichž připomínkování se Národní účetní rada podílela.

Prosinec roku 2012 bude významným mezníkem v činnosti Národní účetní rady, protože mnohaletá práce byla shrnuta do první knižní publikace. V nakladatelství Wolters Kluwer tak vychází první kniha autorů - členů Národní účetní rady, představující systém Interpretací, který vychází ze základního koncepčního dokumentu Předmluva k interpretacím, která je komentována a rozebrána $\mathrm{v}$ publikaci.

Publikace vznikla s cílem představit veřejnosti činnost Národní účetní rady za posledních více než deset let. Zároveň si klade za cíl připomenout požadavky na účetnictví, upozornit na východiska, které je nutno dodržet a rozvíjet, aby docházelo k naplnění požadavků.

Stěžejní část publikace tvoři samotné Interpretace. Ty jsou k dispozici veřejnosti na webových stránkách www.nur.cz, kde je možno sledovat poustup jejich přijímání. Přínosem této publikace je nahlédnutí do procesu tvorby interpretací, je popsán důvod vzniku, průběh diskuse a prípadný podnět pro novelizaci účetních předpisů. V poslední době jsou 
k interpretacím vytvářeny i názorné prríklady. Autoři předpokládají, že čtenáři ocení zejména autorské př́klady, které byly připraveny ke každé interpretaci.

V části knihy byl dán také prostor uživatelům účetních informací a to formou rozhovorů. $\mathrm{Z}$ nich je zřejmá různorodost zájmů jednotlivých skupin uživatelů.

Vážení čtenáři, v závěru si dovoluji popřát Vám krásné a klidné prožití vánočních svátků a do nového roku hodně štěstí a zdraví.

Ing. Jana Skálová, Ph.D.

členka redakční rady Českého finančního a účetního časopisu 